\title{
Health care system takes advantage of doctors' work ethic
}

\author{
C Cite as: CMAJ 2019 May 21;191:E567. doi: 10.1503/cmaj.109-5751
}

Posted on cmajnews.com on Apr. 30, 2019.

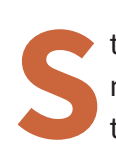

top working so hard and focusing negotiations on monetary issues the health care system will take advantage of you.

That was one message Linda Duxbury, a professor at the Sprott School of Business at Carleton University, had for doctors belonging to the baby boomer generation among the 350 delegates attending the Canadian Conference on Physician Leadership, held recently in Montréal.

Duxbury provided an overview of the changing demographics of the Canadian population, a detailed snapshot of the various generations making up that population, and the implications for physicians and the health care system.

She noted just how different physicians are from the general workforce. The health care system takes advantage of the willingness of physicians to work excessive hours and sometimes provide their time for free, she said. "Hospitals have people who give a damn working for them," and that is how the system survives. She urged physician leaders to fight back against governments who see physician services as an expense rather than a valuable resource.

The health care system is poor at managing change, Duxbury said, and is unprepared for the looming shortage of physicians caused by demographic shifts and the attitudes of younger phys- icians, who aren't as willing to work excessive hours and sacrifice their health. Global demographic changes mean it is also harder to recruit physicians from abroad, and recruiting doctors from poorer nations raises ethical issues, given the health care needs of those countries.

differences need to be acknowledged by health care institutions. He noted that the current generation of medical students and residents are saying "we are unwell, and the system needs to change," whereas older generations of physicians tended to be more resistant to change.

"She was giving us the information ... about how our country is changing, our generations are changing and the way we design and deliver health care has to change," said Dr. Susan Shaw, chief medical officer of the Saskatchewan Health Authority. "We will only be successful if we understand people are changing and their needs are changing, which means we need to meet their needs better."

Shaw noted that over the past 18 months, a younger community of physician leaders has been appointed in

Duxbury said health care organizations will be successful only if they invest in the people who work for them. "Younger physicians want a meaningful existence outside of work and a meaningful experience at work."

Dr. Henry Annan, past president of the Canadian Federation of Medical Students and the student representative on the Canadian Medical Association's board of directors, said he felt Duxbury's characterization of the various generations was accurate overall and that generational
Saskatchewan "and that is a positive thing." But she noted one of the issues identified by Duxbury: the relative shortage of those in the 35-45 age range from whom the next generation of physician leaders will be selected.

"She had a lot of lessons that we should be listening to woven into what she had to present," said Shaw. One of those lessons being that organizations need to "manage and grow your talent."

Pat Rich, Ottawa, Ont. 